\title{
O trovadorismo medieval ibérico e a violência simbólica - séculos XIII e XIV
}

JOSÉ D'ASSUNÇÃO BARROS*

Resumo: O objetivo deste artigo é discutir a violência simbólica presente nas sociedades medievais ibéricas dos séculos XIII e XIV, examinando a poesia e práticas trovadorescas do período. Dentro do contexto histórico da centralização régia do período medieval, o texto analisa algumas cantigas trovadorescas galego-portuguesas nas quais podem ser vistas as tensões sociais entre trovadores oriundos de diferentes categorias sociais, e também envolvendo trovadores em oposição ao rei.

Abstract: The subject of this article is to discuss the symbolic violence in the Iberian medieval societies from the XIII and XIV centuries, examining the troubadours practice and poetry of this period. In the historical context of the medieval centralization around the kingdom, the text analyses Galego-Portuguese chants in witch ones we can see the social tensions between troubadours from different social categories, and also troubadours in opposition in relation to the king.

Palavras-chaves: Trovadores medievais ibéricos. Violência simbólica. Centralização política.

Key words: Iberian medieval troubadours. Symbolic violence. Political centralization.

Eu vos digo que nem comer, nem beber, nem dormir têm tanto sabor para mim como ouvir o grito 'Para a frente', de ambos os lados, e cavalos sem cavaleiros refugando e relinchando, ouvir o grito 'Acudi! Acudi!'e ver o pequeno e o poderoso tombarem na grama das trincheiras e os mortos atravessados pela madeira de lanças adornadas com flâmulas.

(Bertrand de Born, canção de gesta do século XII).

* Doutor em História Social pela Universidade Federal Fluminense (UFF) (Niterói, Rio de Janeiro). Professor dos cursos de Graduação e Mestrado em História da Universidade Severino Sombra (Vassouras, Rio de Janeiro). Professor dos cursos de Graduação em Música do Conservatório Brasileiro de Música (Rio de Janeiro). E-mail: jose.assun@globo.com

Estudos Ibero-Americanos. PUCRS, v. XXXII, n. 2, p. 25-42, dezembro 2006 
Em algumas de suas canções de gesta, o trovador francês Bertrand de Born - que se notabilizaria por ter cantado a guerra como ninguém - consegue explicitar com rara clareza o papel que desempenhava a violência física para os homens medievais. O exercício mais ou menos livre da violência foi, nos primeiros tempos medievais, coisa tão corriqueira como é hoje em dia a observância a certos preceitos de "civilidade". Na verdade, o que hoje entendemos por normas de civilidade foi se consolidando através de um processo secular, onde a violência foi gradualmente adquirindo novas formas e limites normativos, bem como novos caminhos de expressão e de aparências de refinamento que constituem o chamado de "processo civilizador" (ELIAS, 1990).

Com relação à violência do período feudal, é inevitável remontar à própria estrutura simbólica de organização de uma sociedade que previa mesmo a necessidade da presença de um ordo precisamente especializado no exercício funcional da violência. Os bellatores - guerreiros que, de acordo com a teoria da trifuncionalidade, Deus destinara à defesa da sociedade e da cristandade achavam-se livres para lutar uns contra os outros. Sobretudo, encontravam-se livres para oprimir a grande massa de trabalhadores que se distribuía pelas extensas redes feudo-senhoriais. Foi assim que as figuras do "cavaleiro" e do "senhor" convergiram para a figura da nobre, logo se adaptando a uma rede de linhagens que transmitia hereditariamente essa distinção aristocrática que, em um de seus desdobramentos, conferia ao nobre o direito ao exercício da violência física. Com a descentralização feudal do poder, os nobres que exerciam poderes senhoriais detinham privilégios para "tributar" os laboratores sob o seu domínio, ao mesmo tempo em que exerciam sobre os mesmos um rigoroso controle através da violência física. Direitos de tributar e de punir andavam juntos.

É assim que a agressividade, que por vezes se dirigia contra o inimigo externo, tinha em outros momentos o seu uso interno. Cavaleiros saqueando e atormentando camponeses faziam parte da paisagem medieval. Violências desmedidas, praticadas por iniciativa aristocrática - em uma palavra: descentralizadas - ocorriam amiúde. Rixas entre linhagens podiam gerar cadeias insolúveis de vinganças familiares; disputas pela terra alteravam incessantemente a geografia interna dos reinos europeus. E, no meio deste jogo de incontroláveis forças sociais, os laboratores eram fustigados sem grande possibilidade de resistência. Da mesma forma, os senhores podiam tributar os laboratores sob sua jurisdição, e desta maneira o poder da riqueza e o poder das armas apoiavam-se mutuamente, reforçando ambos o poderio de cada senhor feudal. 
É neste contexto de violência que, a partir do século XIII, gradualmente iria começar a se fortalecer uma tendência contrária a esta parcelarização do poder de tributação e de imposição da justiça através dos inúmeros senhores feudais. A história política dos vários reinos europeus a partir do século XIII, cada qual com seu próprio ritmo e suas especificidades, será em boa parte a história desta tensão entre uma tendência centralizadora que começa a se gestar a partir do poder régio e aquela tendência oposta de lutar pela conservação da autonomia senhorial que veremos em diversos setores da nobreza.

Portugal e Castela - reinos hispânicos que, em função de especificidades que já discutiremos, antecipam os processos de centralização nas mãos do rei - têm a sua história entretecida precisamente a partir destas tensões que se dão no contexto das lutas da Reconquista. Teremos aqui uma história de violência concreta, como, aliás, ocorre em todos os processos históricos que envolvem guerras contra inimigos externos e disputas internas pelo poder, mas também uma história de violências simbólicas, de projeção das lutas políticas no plano da cultura, de sujeição não apenas a partir das armas, mas também através do discurso.

O nosso objetivo será examinar como se projeta e se refrata nos meios trovadorescos da época esta violência simbólica gerada em um contexto de embate entre a centralização régia dos reinos hispânicos e a luta pela conservação de autonomia senhorial por parte de alguns setores da nobreza. Teremos oportunidade de verificar como, sobre este contexto, aparecem confrontadas as várias categorias sociais através de uma poesia que se abre criativamente para o confronto simbólico através destes gêneros poéticos bastante específicos que são as tenções e as cantigas de escárnio e de mal dizer.

O embate centralizador inicia-se em Portugal e Castela no momento mesmo em que se inicia o processo da Reconquista. Existem alguns momentos privilegiados para examinar este embate entre os setores favoráveis à centralização e os fatores que resistiam a esta mesma centralização régia. Para a questão mais específica que nos interessa - a da violência simbólica - um dos períodos mais interessantes para o estudo do centralismo monárquico nos reinos hispânicos é o momentum centralizador do Portugal e da Castela da segunda metade do século XIII. Reis como D. Afonso X de Castela, e D. Afonso III e D. Dinis de Portugal, edificaram uma estudada política de centralização que tinha grande preocupação com os desdobramentos culturais e imaginários da sociedade que 
pretendiam governar. Construíram para si uma imagem de "reis sábios", em torno da qual passaram a edificar uma corte sofisticada que pretendia se apresentar como um suporte cultural para a sua prática política centralizadora.

Desde cedo, estes monarcas viram a necessidade de caminhar não apenas em direção a um controle da violência militar, facilitado pelo seu papel de regentes máximos das operações militares da Reconquista. Era preciso caminhar também em direção a um "controle simbólico" da violência social. Para isso se prestou admiravelmente a difusão da imagem de um rei "árbitro de conflitos". Em uma sociedade aristocrática em crise, pontuada pelas mais diversas rivalidades linhagísticas e internobiliárquicas, a imagem do "árbitro de conflitos" era um meio de convencer parte da nobreza acerca da necessidade de seu projeto centralizador.

Dom Afonso X de Castela e seus contemporâneos de Portugal logo compreenderam que o movimento cultural dos trovadores, em vias de declinar em algumas partes da Europa, ajustava-se esplendidamente às estratégias culturais que poderiam beneficiar os seus projetos políticos centralizadores. O trovadorismo era um movimento poético-musical que atravessava todas as classes sociais, e por isso podia representar a pluralidade social. Trazer esta multiplicidade trovadoresca para dentro de suas cortes era trazer para ali o confronto entre os diversos tipos sociais, era criar um espaço especial, quase catártico, para este confronto. Era trazer para dentro da corte a pluralidade social e submetê-la à arbitragem real.

Daí que um movimento trovadoresco de corte "tardio" em relação aos seus congêneres europeus (ganha força precisamente quando o movimento trovadoresco provençal começa a entrar em declínio) torna-se peça fundamental nestes "precoces" processos centralizadores que se dão nos dois reinos do ocidente hispânico. Enquanto em outras partes da Europa o trovadorismo havia sido um fenômeno feudal por excelência, no ocidente ibérico ele é claramente incorporado ao centralismo régio.

No trovadorismo das cortes ibéricas ganha um extraordinário relevo, menos comum nos demais ambientes trovadorescos da Europa, a poesia satírica. Por meio destes poemas satíricos, estabelecem-se verdadeiros confrontos líricos entre os vários tipos sociais. Um vilão é livre para se opor a um trovador nobre nesta "arena dos trovadores". O vilão deve se defender do jogral assoldadado, da mais baixa extração social, com as mesmas armas poéticas. O nobre partidário da descentralização senhorial é livre para se opor, desde que liricamente, ao monarca centralizador. Até mesmo o rei-trovador participa do disputatio lírico convivendo com 
todos os demais tipos sociais e submetendo-se às mesmas normas que regem o conjunto dos poetas-cantores. $\mathrm{Na}$ "arena dos trovadores" ele deve vencer pelo talento, e não pelos seus atributos régios. Mas quando não estiver poetando - e estiver desempenhando a função de anfitrião maior do paço trovadoresco - deve ocupar sua habitual posição de árbitro de conflitos.

Trazer esta disputatio lírica para dentro da corte significa trazer para o âmbito palaciano a "violência simbólica" do reino; significa criar um espaço especial, legitimado pela presença do monarca, para as disputas sociais; significa deslegitimar qualquer espaço de confronto externo ao paço. Trazendo a crítica social para perto de si, o monarca se previne de tê-la longe de si, na praça pública, onde fatalmente escaparia de seu controle e ganharia todos os ouvidos sociais. Dentro do paço, esta crítica relativamente livre é reeducada, atentando a certas regras trovadorescas e limitando-se a um palco e a um intervalo de tempo que coincide com os saraus palacianos.

É por isso que o monarca que rege um paço trovadoresco aceita com bastante tranqüilidade as cantigas satíricas que são compostas e direcionadas contra a sua própria figura, que afinal de contas, por ocultos caminhos de constrangimento impostos pela proximidade do monarca, não serão tantas quanto as cantigas satíricas de alguns nobres contra os outros, de vilãos contra nobres, de jograis assoldadados contra vilãos e fidalgos, e assim por diante. Acima de todos estes conflitos, o rei poderá pairar como um árbitro que coloca a disputatio lírica em movimento. Isso não impedirá, por outro lado, que um ou outro trovador seja mais ousado na sátira contra o monarca.

Neste contexto e de acordo com estas motivações sociopolíticas, logo emergiria do universo satírico ibérico um gênero poético particularmente caro aos trovadores envolvidos na disputatio lírica. ${ }^{1}$ Trata-se das "tenções". O gênero era já conhecido nas cortes

1 As fontes que aqui utilizaremos correspondem ao chamado Cancioneiro GalegoPortuguês, que reúne em três documentos principais a poesia palaciana tanto de Portugal como de Castela entre os séculos XIII e XIV, já que estes dois reinos constituíam pólos de um mesmo movimento trovadoresco. O Cancioneiro da Ajuda, o Cancioneiro da Vaticana e o Cancioneiro da Biblioteca Nacional têm suas origens entre a última década do século XIII e as primeiras décadas do século XIV, e constituem grandes coletâneas da poesia trovadoresca ibérica que, à sua época, circulava nas cortes régias de Portugal e Castela. O Cancioneiro da Ajuda teria sido posto por escrito no próprio período do reinado de Afonso X de Castela, ainda na segunda metade do século XIII. Já os outros dois cancioneiros, postos por escrito no século XVI, originamse de um Livro de Cantigas da primeira metade do século XIV que depois teria desaparecido. Os manuscritos encontram-se atualmente nas bibliotecas que lhes emprestam 
provençais e na minnesang. A forma constituía-se basicamente de uma alternância de estrofes, onde um trovador respondia ao outro a maneira de um desafio. O dado fundamental é que, nas cortes feudais européias, mesmo que estas disputationes líricas envolvessem trovadores aristocratas e menestréis de categoria social inferior, o tema central da tensó jamais costumava envolver uma questão de fundo social. Discutia-se em torno da "amatória" (questões relativas ao amor cortês), ou então sobre "estilística" (um verso deveria ser transparente como as águas de um rio ou obscuro como as brumas de uma tarde de outono?).

Ao contrário, na "tenção" ibérica", o conteúdo mais habitual é claramente social, gerador de confrontos de todos os tipos. Nos paços trovadorescos de Portugal ou Castela, era bastante comum que dois tipos sociais antagônicos, como um jogral assoldadado e um trovador fidalgo, duelassem liricamente com conotações sociais:

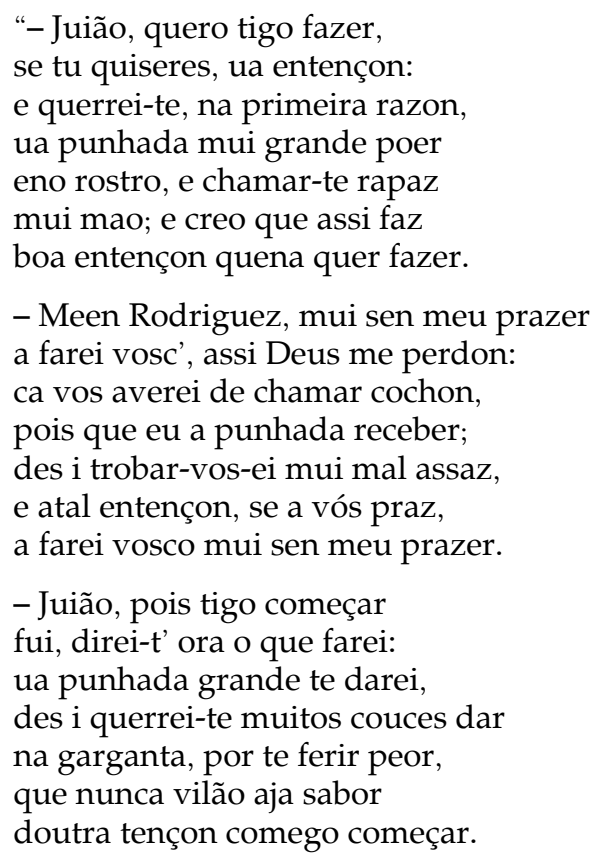

seus nomes: Biblioteca da Ajuda (CA), Biblioteca da Vaticana (CV), Biblioteca Nacional (CBN). Os três cancioneiros encontram-se atualmente impressos, contando com edições importantes das quais elegemos a de Carolina Michaëlis de Vasconcelos para o Cancioneiro de Ajuda (1904), a de Teófilo Braga para o Cancioneiro da Vaticana (1878), e a de Elza Pacheco Machado para o Cancioneiro da Biblioteca Nacional (1949-1964). No presente artigo, as abreviaturas $\mathrm{CA}, \mathrm{CV}$ e CBN corresponderão às cantigas incluídas em um ou outro destes cancioneiros. 
- Meen Rodriguez, querrei-m' en parar, se Deus me valha, como vos direi: coteife nojoso vos chamarei, pois que eu a punhada recadar; des i direi, pois so os couces for: 'Le[i]xade-m' ora, por Nostro Senhor', ca assi se sol meu padr' a en parar.

- Juião, pois que t' eu [for] filhar pelos cabelos e que t' arrastrar, que dos couces te pès eu creerei.

- Meen Rodríguez, se m' eu estropiar, ou se me fano, ou se m' entortar, ai, trobador, já vos non travarei".

(Meen Rodríguez Tenoiro e Juião Bolseiro; CBN 403).

A estrutura de tenção é típica: através dela, os dois trovadores se ocupam de depreciar um ao outro em estrofes alternadas. Dentro desta estrutura, ao invés da tenção girar em torno de uma questão genérica, o que se vê é uma sucessão de ataques pessoais que oculta um verdadeiro conflito de categorias sociais.

Mem Rodrigues Tenório pertencia a uma das mais ilustres famílias galegas e à melhor nobreza da Península. Quanto a Juião Bolseiro, era um jogral que também atuava com sua margem de atrevimento, embora muito menos que Lourenço - outro jogral da época que se celebrizou por afrontar trovadores-fidalgos - mas que aqui aparece curiosamente comedido diante das ameaças de Tenório.

Estamos aqui diante de uma tenção proposta em termos de rara agressividade. Quase que toma a forma lírica de uma "briga de rua", não fosse o fato de que, à total agressividade de Tenório, Juião Bolseiro replica com certo comedimento. Enquanto o fidalgo principia por dizer que sua primeira razão é um murro no rosto (v. 4/5), Juião no máximo o responde com alguns insultos ("cochon", por exemplo, que é uma expressão pejorativa normalmente dirigida por aristocratas a vilãos). Talvez, sem querer partir para o que poderia descambar para um confronto físico, ou então extrapolar a tensão trovadoresca apresentada liricamente, o jogral tenta responder com mais dignidade e astúcia poética. Apropria-se então das próprias palavras injuriosas que os nobres costumavam dirigir aos vilãos e procura voltá-las contra o fidalgo agressor, talvez a insinuar algo sobre quem se comporta como um verdadeiro "cochão" (v. 10), ou ainda um "coteife nojoso" (v. 24). 
Tenório, por sua vez, continua ao longo de todas as estrofes a desfechar suas ameaças físicas, como, por exemplo, na terceira estrofe, onde afirma que "irá lhe dar muitos coices na garganta, para feri-lo tanto que desde então nenhum vilão mais se atreverá a entençoar com ele" (v. 18/21). É a demarcação social levada a seu extremo, com rara agressividade em uma tenção trovadoresca neste meio em que tudo parece se resolver liricamente.

Significativo nos parece o contraste entre a agressividade do nobre e o relativo comedimento do jogral, pois nos mostra que os limites de um não são iguais aos limites do outro. De qualquer forma, deve-se ter em vista que estas tensões se davam habitualmente em um ambiente lúdico, contrapontado pelo riso, de modo que não devemos entender a agressividade simbólica desfiada através dos versos como afrontas em vias de se concretizarem. Em todo o caso, o exemplo acima fica como um registro extremo desta oposição entre dois representantes de segmentos sociais que se antagonizam através da sátira trovadoresca - oposição que, na maior parte das vezes, concentra-se na disputa estritamente lírica, na desmoralização pelo riso, no rebaixamento pela palavra. $\mathrm{O}$ "combate corpo a corpo" assume em quase todos estes casos a forma de um "combate verso a verso", e se volta fundamentalmente para o campo da "violência simbólica".

Se eram comuns os confrontos poéticos envolvendo trovadores pertencentes a diferentes categorias sociais, um aspecto muito singular do trovadorismo ibérico é que o próprio rei podia ser confrontado através do verso, e não raro se valiam disto os trovadoresfidalgos que se opunham ao projeto régio de centralização, ou então aqueles que tinham outras pendências em relação ao monarca. $\mathrm{O}$ trovador que mais se celebrizou por contrapor-se liricamente a um monarca foi o fidalgo Gil Peres Conde. Exilado na corte do rei de Castela, nem por isso poupou de sutis e bem-humoradas críticas ao seu novo suserano. Consideraremos alguns destes escárnios, não sem antes recuperar um pouco da biografia de seu autor.

Gil Peres Conde era filho do fidalgo Pero Gil Feijó, além de ter sido casado com uma irmã do trovador João Soares Coelho, do qual já falaremos. Estes dados não são irrelevantes, se os juntarmos aos acontecimentos que atravessaram a trajetória do fidalgo. Supõe-se que estivesse no número daqueles que tomaram o partido de D. Sancho II contra D. Afonso III, na já discutida crise de 1245. Por isto, viu-se obrigado a pedir asilo em Castela, a partir de 1248. Como muitos outros portugueses, serviu com dedicação a Afonso $X$ de Castela: em 1269, é indicado pelo monarca para defender o alcácer de Baeza e colonizar as Terras de Xarafe e a Torre de Gil de Olite; e em 1273 já o localizamos na situação honrosa de "jurado por el-rei" 
(LAPA, 1981, p. 163/164). Mais tarde encontrava-se ainda aos serviços de Castela, como infanção na corte de Sancho IV. Em 1286 recebia um subsídio de 2.000 maravedis para acompanhar o rei à entrevista de Baiona com o rei da França, mercê também recebida pelo trovador Rodrigo Eanes Redondo.

Coloquemos estes dados em movimento. $\mathrm{O}$ trovador era proveniente da alta nobreza portuguesa. Reduz um pouco o seu nível com o exílio em Castela, tornando-se apenas um infanção (isto é, perdendo o status de rico-homem). Goza, contudo, de algum prestígio, conforme as mencionadas mercês recebidas pelo rei. Daí já fica assinalada uma certa proximidade, ainda que uma proximidade crítica, com relação ao monarca. De antemão, pode-se dizer que os escárnios contra o rei, filtrados por uma fina ironia, pressupõem um certo nível de cordialidade. Diríamos que de "familiaridade", ainda que ambígua. Trava-se, no fundo, um embate entre dois campos de idéias: a mentalidade feudal e a centralizadora. Embate radical, mas possível de se concretizar em críticas mais diretas pela proximidade amistosa.

O exílio em Castela por discordar da deposição de D. Sancho II define sua posição política junto a outros fidalgos, como o já citado Airas Peres Vuitoron, e o coloca em oposição aos partidários de D. Afonso III, inclusive seu cunhado João Soares Coelho, que se passou em certo momento para o lado do novo rei. A dedicação no serviço ao rei vizinho define a sua mentalidade feudal: o importante é servir o novo suserano em um sistema de obrigações recíprocas e pautadas pelo código cavaleiresco. Contam menos aqui as coordenadas de índole regional: o nobre é nobre onde quer que esteja, e pode propor vassalagem na corte vizinha. Pela mentalidade feudal que o trovador expressa, e pelas circunstâncias de seu exílio, tornam-se secundárias eventuais rivalidades que logo no século seguinte formatariam mais precisamente as identidades nacionais. Ainda que, pelo menos em uma cantiga, o trovador se queixe do tratamento distante que recebe dos castelhanos (CBN 1525).

A posição das idéias do trovador dentro do circuito imaginário feudal é definida pela precisão com que ele defende, nos seus escárnios, conceitos caros ao ideário feudo-vassálico. Seu relacionamento com o rei é encarado por ele mesmo como o de um vassalo para com o seu suserano, sempre pronto a exigir deste último o cumprimento de suas obrigações no mecanismo de reciprocidades vassálicas. Já o rei, deixa entrever no seu relacionamento com o vassalo português um outro tipo de mentalidade, a do monarca centralizador que apenas usa o ideário feudal para fortalecer sua própria proposta centralizadora. 
É assim que se insinua na relação entre ambos este confronto entre duas mentalidades - vale dizer, o próprio embate centralizador refratado no plano mental e expresso no lirismo escarninho. Veremos que várias cantigas do fidalgo confirmam esta posição. Da mesma forma, Gil Peres Conde alinha-se a outros elementos da nobreza mais tradicional na defesa de uma "posição de classe", inclusive no que se refere ao desprezo voltado aos segmentos sociais abaixo daquela (ver a CBN 1515 contra "um jogral que se metia a trovador"). Estabelecidas estas coordenadas que recolocam política e socialmente os dados biográficos do trovador, consideremos agora as cantigas que expressam as tensões contra o rei Afonso X.

\footnotetext{
"Os vossos meus maravedis, senhor, que eu non ôuvi, que servi melhor ou tan ben come outr'a que os dan, ei-os d'aver enquant'eu vivo for, ou a mia mort', ou quando mi os daran?

A vossa mia soldada, senhor Rei, que eu servi e serv'e servirei, com'outro quen quer a que dan ben, ei-a d'aver enquant' a viver ei, ou a mia mort', ou que mi faran en?

Os vossos meus dinheiros, senhor, non pud'eu aver, pero servidos son, Come outros, que os an de servir, ei-os d'aver mentr'eu viver, ou ponmi-os a mia mort' o a que os vou pedir?

Ca passou temp' e trastempados son, ouve an'e dia e quero-m' en partir".
}

(Gil Pérez Conde, CBN 1524).

A cantiga acima é uma das mais engenhosas do cancioneiro escarninho. O fidalgo, que servira ao rei na guerra da Andaluzia, queixa-se das dificuldades em obter as soldadas correspondentes aos serviços prestados. Em outras palavras, acusa o rei de "mau pagador" - o que neste caso significa acusá-lo de mau cumpridor das obrigações geradas pelos vínculos de vassalidade. Os artifícios poéticos encontrados pelo nobre são engenhosos e bem humorados. Joga com o duplo uso de pronomes possessivos, "vossos" e "meus", referindo-se aos maravedis que estavam de posse do rei, mas que por direito deveriam ser seus. "Os vossos meus maravedis", "A vossa mia soldada", "Os vossos meus dinheiros" - o trova- 
dor pergunta se os receberá durante a vida ou somente à hora da morte. Em outra cantiga (CBN 1522, adiante discutida) chega a pedir "um bom fiador" para que possa ir à próxima cavalgada.

O "duplo possessivo" aqui empregado, com originalidade absoluta, é um exemplo notável daquela capacidade de trazer o confronto para dentro de uma única expressão. Tornada ambígua, e provavelmente acompanhada de uma entonação irônica no plano da oralidade, a palavra poética expressa aqui o entrechoque de dois interesses. O do monarca, que naqueles tempos perturbados e de dificuldades econômicas acabava por vezes atrasando as soldadas, e o do vassalo, exigindo o pagamento imediato, já veremos que por considerá-lo uma obrigação suserana. Brigam os dois possessivos, "meus" e "vossos", disputando o espaço com que se colam ao substantivo que para o fidalgo representa um "direito", mas para o monarca se insinua como uma "obrigação". O entrechoque poético e inusitado entre os dois possessivos é desta forma o entrechoque entre um direito e uma obrigação, entre o vassalo e o suserano, entre uma necessidade e outra. Quantas disputas secretas não se insinuam neste torneio imaginário que se celebra no interior de uma única palavra poética!

Além de uma queixa contra a dívida não paga, deve-se buscar nesta cantiga o texto sob o texto: ela invoca indiretamente o próprio conjunto de instituições feudo-vassálicas, e coloca o monarca na posição de um suserano que se beneficiou dos serviços do vassalo, mas recusa-se a cumprir suas obrigações de suserano. Competem, desta forma, o modelo do "bom vassalo" e o contramodelo do "mau suserano".

Vejamos agora que por trás destes combates se dá um outro. É o próprio "embate centralizador" que produz sua centelha a partir do entrechoque destas muitas espadas. O "rei centralizador" é muitas vezes um "mau suserano". Nos tempos mais difíceis a sua necessidade o leva a unilateralizar uma obrigação que, no ponto de vista estritamente "feudal", deveria carregar a inseparável sombra da reciprocidade. Enquanto isso o vassalo nobre, "bêbado de sua própria necessidade" e situado no campo adverso, invoca o único brasão que para ele tem valor, que é o próprio ideal cavaleiresco com todas as suas insígnias de mútua fidelidade. É assim que o próprio reino, enquanto totalidade, enfrenta dialogicamente as partes que o constituem: poderes, terras e pedaços de um imaginário de que se serve para construir, lenta, mas precocemente, a sua identidade nacional.

Vista pelo circuito dos ideais vassálico-cavaleirescos, a expressão "senhor" repetida em cada uma das três estrofes (por 
exemplo, "senhor rei") assume um sentido a mais além do vocativo respeitoso, remetendo às obrigações de senhor (suserano) que o rei teria descumprido. Por tudo isso se vê que, dentro de um contexto em que vem se dando no plano político o "embate centralizador", a cantiga compõe com outras do mesmo trovador uma defesa dos direitos senhoriais. Na já citada CBN 1522 isto fica ainda mais claro. Sem um "bom fiador", que garanta da parte do rei o fiel cumprimento de suas obrigações de suserano, o fidalgo declara que irá valer-se de sua autonomia permanecendo "em sua pousada":

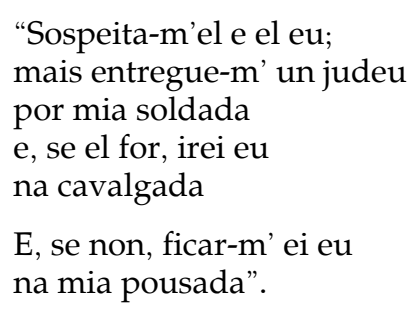

(Gil Pérez Conde; da CBN 1522, estrofes finais).

Exigir um "fiador", em um universo de valores vassálicos fundamentado na honra e na fidelidade, concede à cantiga não apenas uma solução bem humorada como também uma crítica mordaz ao monarca centralizador, que invoca a fidelidade vassálica apenas quando lhe interessa (CBN's 472, 486, 493, 496). Se recolocarmos o dado de que Gil Peres Conde é um fidalgo português exilado em Castela, justamente por ter discordado de uma monarquia que se estabeleceu em Portugal a partir da quebra de vínculos de vassalidade (traição dos partidários de D. Afonso III ao rei deposto D. Sancho II), podemos aventar ainda que as suas cantigas têm um segundo alvo na figura do novo monarca português. A poesia do trovador-fidalgo assume, assim, a forma de um instrumento de muitas faces.

Também teremos aqui uma poesia reveladora da crise nobiliárquica. Sempre que são perturbados pelas dificuldades econômicas, os nobres preocupados com a pureza do ideal cavaleiresco se vêem em situação difícil. Interditam a si mesmos opções de autosubsistência que depreciam como atividades não-aristocráticas (o comércio, por exemplo; ou então a usura, depreciada na cantiga anterior com a referência ao personagem judeu). Logo, com os espaços não-aristocráticos interditos, e presos na própria teia de seu imaginário, os nobres mais tradicionais dependem das atividades e recursos preceituados pelo ideário cavaleiresco. Na cantiga abaixo, Gil Peres Conde nos dá mostras desta crise nobiliárquica: 


\begin{abstract}
"Mentr' esta guerra foi, assi m' avéo que sempre guari per pé de cavalo; mais òi mais non sei que ela seja de mi senon guarir per pé de boi.
\end{abstract}

Quantos perígoos i passei per pé de caval', e 'scapei, que non prix i cajon!, mais ôi mais non sei eu que mi farei senon guarir per pé de boi.

Por valer mais e por aver, conselh' ôvi de guarecer per pé de cavalo; mais ôi mais non sei a que mi afazer senon guarir per pé de boi.

Lavrar, lazerar, e viver ôi mais, guarir per pé de boi!".

(Gil Pérez Conde; CBN 1523).

O fidalgo português já não prosperava tanto quanto no início de seus serviços ao rei de Castela. Conta-nos que na guerra (1264-1265) conseguira guarir (enriquecer) rapidamente. Para definir a rapidez de enriquecimento, devido aos seus feitos de armas, utiliza a expressão "por pé de cavalo". Contudo, com a suspensão das hostilidades se via "esquecido pelo rei". A sua fortuna ia agora "por pé de boi", muito lentamente (LAPA, 1975, p. 248). Tem agora que lazerar (penúltimo verso), isto é, sofrer, penar, curtir miséria.

O trovador nos mostra, assim, a posição de um setor específico da nobreza, muito dependente das atividades de guerra. Setor que reúne nobres em posições diversas no conjunto aristocrático: desde os exilados de outras terras até os filhos segundos, estes que, postos à margem de um sistema de herança que beneficia a primogenitura, têm de recorrer com maior necessidade à participação em atividades bélicas. Mais uma vez o poeta critica abertamente o monarca, esquecido de seus méritos agora que não precisa dele de maneira mais imediata. $\mathrm{O}$ que vale por uma nova crítica à suserania real, não provendo as necessidades do vassalo no momento de crise.

A cantiga é também um sinal dos novos tempos. Não apenas o setor mais dependente das atividades guerreiras, mas a nobreza como um todo, tinham como destino inexorável a decadência no 
longo prazo, mesmo que suspensa nesse ou naquele tempo por breves períodos de "revanche nobiliárquica". Era a própria importância social da nobreza que estava condenada a "fugir por pé de boi", lentamente através dos séculos. Ver esvair a sua fortuna, o seu prestígio, o seu papel de controle social, e tudo o mais que tinha até então composto a sua importância política, era esse o desfecho inevitável da grande tragédia aristocrática. A monetarização, a ascensão dos grupos não-nobres, a centralização do poder estatal, eis aí os sinais deste novo tempo cujo centro de gravidade em breve completaria a sua inclinação para a burguesia e para a centralização régia.

As lutas da Reconquista, oferecendo à nobreza oportunidades que nem sempre correspondiam a um crescimento estrutural, ocultavam à aristocracia ibérica a inevitabilidade do seu destino. "A comoção e a inquietação, a confirmação do valor próprio na luta, a possibilidade de pilhagem e a facilidade de ganho, tudo isso estimulou a nobreza a acreditar que podia manter sua posição social, embora ameaçada, e salvar-se da decadência e do empobrecimento" (ELIAS, 1990, p. 161). Esse fenômeno que seria geral na Europa em momentos diversificados, teria nos palcos da Reconquista uma expressão particular. Um nobre como Gil Peres Conde podia enriquecer rapidamente devido à pilhagem e ao saque, mas assim que cessavam as hostilidades não podia fugir à visão profética de seu futuro, do futuro de sua própria classe: tudo o que ganhara em tão curto tempo terminaria por escoar-se lentamente através dos anos. O ideário cavaleiresco, impedindo os nobres de se entregarem a atividades burguesas, comprimia suas oportunidades sociais dentro de um modelo que era já de outro tempo, mas com o qual nostalgicamente sonhavam. Eram esses sonhos cavaleirescos que levavam Gil Peres Conde a criticar alguns monarcas como maus suseranos.

Se Gil Peres Conde encaminha a crítica ao "mau suserano", é preciso não esquecer que ele alveja com a mesma ironia o "mau vassalo". Já vimos que sua produção poética está ancorada firmemente no ideário cavaleiresco, conforme se nota também nas cantigas que volta contra os nobres que não lhe parecem corresponder ao seu modelo cavaleiresco. Assim, critica nesses nobres a covardia, a infidelidade, o não-cumprimento das obrigações vassálicas.

Na CBN 1518 lança um escárnio contra os cavaleiros que fraquejaram na guerra da Andaluzia. Imagina um decreto-real que os proibisse de comer "carne-de-galinha", o que, de acordo com uma 
tradição popular, fazia perder a coragem. Na CBN 1517 alveja um cavaleiro que alega perdas na última guerra, a pretexto de não entrar na seguinte. Na CBN 1516 dirige um remoque a um ricohomem que se apresenta na guerra bem diferente do que um dia fora: homens e armas mudados, e também a audácia substituída por uma prudência que raia a covardia. Na CBN 1520 dirige-se contra um cavaleiro que recebia soldadas do rei para a luta contra os mouros, mas não se armava como devia. Então o autor pergunta-lhe se aquele dinheiro seria a título gracioso, "sem obrigações" por parte do contemplado. É isso que se deve entender por "se lho dan por aguilhando" (LAPA, 1975, p. 240):

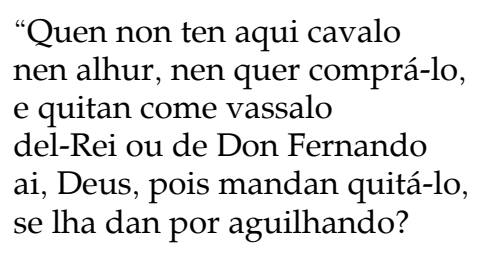

Quen nunca trouxe 'scudeiro nen comprou armas d'armeiro, quitan come cavaleiro del-Rei ou de Don Fernando? Ai, Deus, tanto bon dinheiro se lho dan por aguilhando?".

(Gil Pérez Conde; CBN 1520, duas últimas estrofes).

Compreende-se, assim, que o fidalgo-português exige obrigações e cumprimentos de obrigações nas duas pontas do relacionamento entre suserano e vassalo. Com o mesmo rigor constrói os modelos do suserano e do vassalo. Não é à toa que, na primeira cantiga que analisamos ("os vossos meus maravedis"), continua afirmando que, apesar das extensas queixas quanto ao não-cumprimento dos compromissos pelo suserano régio, pretende continuar servindo-o ("A vossa mia soldada, senhor Rei,/que servi e serv' e servirei"). Atenuante para suas pesadas críticas? Reconhecimento de limites? Ironia? Derradeira crítica que opõe a imagem do "bom vassalo", em si mesmo realizada, à do "monarca mau suserano"? Ou todas estas alternativas a um só tempo, encaminhadas através deste discurso poético que é o único que poderia torná-las multipresentes?

A verdade é que a posição de Gil Peres Conde, solidamente atrelada ao imaginário feudal, podia por vezes destoar do que efetivamente ocorria no concreto vivido. Cumprir sua parte, por uma questão de honra, mesmo sem a reciprocidade do suserano, 
seria uma atitude pouco prática para boa parte dos cavaleiros. O próprio ideário feudo-vassálico previa o diffidatio (ruptura da fé), que era um rompimento do contrato vassálico em função do não cumprimento de obrigações suseranas. Desta forma, inclinamo-nos a ver na idéia de "honra a qualquer custo" uma figura de força que o trovador empunhava simultaneamente contra as atitudes de má-vassalagem e má-suserania.

Rigorosamente, os vínculos dentro das ramificações nobiliárquicas deviam ser regados cotidianamente. "A lealdade dos vassalos era, afinal, regulada exatamente pelo grau de dependência entre as partes, pelo jogo da oferta e procura entre os que davam terra e proteção em troca de serviços, por um lado, e aqueles que deles necessitavam, por outro" (ELIAS, 1990, p. 64). Se a malha de interdependências não fosse firme o suficiente, com fios trançados de parte a parte, pouco se poderia evitar com todo o imaginário cavaleiresco - que o vassalo trocasse mais ou menos facilmente de suserano.

Nos tempos de crise, a "movência vassálica" intensifica-se sensivelmente. Dela sabe bem se apropriar o monarca. Com o cuidado de se estabelecer como o "alfa" e o "ômega" da teia de interdependências vassálicas, para o que reforça a idéia de que em última instância todos são vassalos diretos do rei, o monarca produz em torno de si um equilíbrio móvel. No centro da teia, elege este ou aquele fio, estas e aquelas linhagens como caminhos privilegiados para o acesso às oportunidades de poder. No momento seguinte, redistribui mais uma vez o poder, e com isso dinamiza a tendência de circulação cavaleiresca. Todos permanecem amarrados à sua figura, mas em torno de si a teia se movimenta.

É esta "movência vassálica" para além de certos limites, recorrente no concreto vivido, que se choca contra a visão de mundo de Gil Peres Conde, regrada pelo imaginário cavaleiresco e pouco flexível no que se refere aos laços de vassalagem e suserania. A homenagem e a investidura, permeadas pelo seu próprio conceito de "fidelidade", são para ele referências sagradas. Ao mesmo tempo, uma obrigação que não gera benefício (CBN's 1522 e 1523), ou um benefício sem a correspondente obrigação (CBN 1520), são para o trovador verdadeiros absurdos. Quanto ao vínculo entre esses pólos inseparáveis, é principalmente contra o rompimento injustificado de compromissos de reciprocidade, parta ele de um cavaleiro ou do rei, que seus versos se insurgem. Canta neles o contraponto entre um mundo imaginário de rigorosas interdependências vassálicas, onde o rei é visto apenas 
como um suserano maior, e o mundo concreto dos cavaleiros que já começam a se mover mais livremente em função da oferta e da procura, do rei que por vezes transcende a visão senhorial do reino para prenunciar vagamente um novo tipo de organização nacional, da sociedade que já não cabe - ou nunca coube - no ordenamento tripartido. Para trás, no imaginário e no tempo, em um mundo embalado pelas canções de gesta de além-Pirineus, já ficara talvez essa cavalaria de que Gil Peres Conde se orgulhava. Dos antigos heróis, como um Guilherme Marechal - esse último e "maior cavaleiro do mundo" - um exilado ibérico como Gil Peres Conde não podia ser mais que um pálido reflexo. Sequer seria ele "uma forma residual, uma relíquia", tentando também o seu derradeiro "triunfo da honra sobre o dinheiro, da lealdade contra o Estado" (DUBY, 1988, p. 211). Nesses tempos de paz magra, onde a fortuna de um cavaleiro escoa "por pé de boi", ele dificilmente pode passar de uma melodiosa queixa entrincheirada no cancioneiro galego-português. Mas, enfim, mesmo ao abrigo do monarca castelhano, o trovador português não deixa de encontrar um espaço para criticar a própria realeza de seu tempo.

A violência simbólica, enfim, abre-se no palco trovadoresco dos paços ibéricos para todos e contra todos os atores sociais, inclusive o rei. As diversas cantigas satíricas, que hoje podem nos falar com razoável eloqüência das relações sociais e políticas presentes nas sociedades ibéricas dos séculos XIII e XIV, revelam os limites da pluralidade e da liberdade trovadorescas. Limites móveis, variáveis - ora mais demarcadores, ora mais difusos. Limites também denunciadores de ambigüidades que habitam o próprio inconsciente nobiliárquico, revelando o universo pulsional de amor e ódio, de revolta e submissão, de admiração e inveja, que pauta as relações entre nobreza e realeza.

\section{Referências}

Cancioneiro da Ajuda. Editado por Carolina Michaëlis de Vasconcelos. Halle: 1904. 2 v.

Cancioneiro da Biblioteca Nacional. Organizado por Elza Paxeco Machado e José Pedro Machado. Lisboa: Ocidente, 1949-1964.

Cancioneiro Portuguez da Vaticana. Edição de Teófilo Braga. Lisboa: 1878. 
BARROS, José D'Assunção. A Arena dos Trovadores - as representações das tensões sociais no cancioneiro medieval ibérico (séculos XIII-XIV). Niterói: UFF, 1995 (dissertação de mestrado).

. As três imagens do Rei - o imaginário régio nas narrativas dos livos de linhagens e nas cantigas trovadorescas (Portugal e Castela, séculos XIII e XIV). Niterói: UFF, 1995 (tese de doutorado).

DUBY, Georges. As Três Ordens ou o Imaginário do Feudalismo. Lisboa: Estampa, 1982. Graal, 1988.

ELIAS, Norbert. O Processo Civilizador. Rio de Janeiro: Jorge Zahar Editor, 1990.

. A Sociedade de Corte. São Paulo: Cia. das Letras, 1995.

LAPA, Manuel Rodrigues. Lições de Literatura Portuguesa. Coimbra: 1981.

. Cantigas D'escarnho e de mal dizer. Lisboa: Galáxia, 1975. 